\title{
PERAN GENDER DALAM PENGAMBILAN KEPUTUSAN PEMILIHAN METODE KONTRASEPSI DI PUSKESMAS PATTALLASSANG KABUPATEN GOWA TAHUN 2016
}

\author{
Fatmawaty Mallapiang ${ }^{1}{ }^{*}$, Azriful $^{2}$, Rini Jusriani ${ }^{3}$ \\ Bagian Kesehatan dan Keselamatan Kerja Kesehatan Masyarakat UIN Alauddin Makassar ${ }^{1}$ \\ Bagian Epidemiologi Kesehatan Masyarakat UIN Alauddin Makassar ${ }^{2}$ \\ Bagian Gizi Kesehatan Masyarakat UIN Alauddin Makassar ${ }^{3}$ \\ ${ }^{*}$ E-mail : fatmawaty.mallapiang@uin-alauddin.ac.id
}

\begin{abstract}
Abstrak
Penelitian ini bertujuan untuk mengetahui peran gender dalam pengambilan keputusan pemilihan metode kontrasepsi di Puskesmas Pattallassang Kabupaten Gowa. Penelitian ini adalah survey deskriptif untuk mengetahui peran gender dalam pengambilan keputusan pemilihan jenis kontrasepsi pada pasangan usia subur. Sampel sebanyak 86 responden merupakan isteri dari pasangan usia subur yang merupakan akseptor KB di wilayah kerja Puskesmas Pattallassang Gowa. Hasil penelitian menunjukkan bahwa suami mendominansi pengambilan keputusan menggunakan kontrasepsi (89,5\%), dan pemilihan metode kontrasepsi $(57,0 \%)$ di wilayah kerja Puskesmas Pattallassang Kabupaten Gowa. Sementara isteri masih lebih banyak yang mempercayakan pengambilan keputusan pemilihan metode kontrasepsi kepada suami (57,0\%), namun perannya lebih terlihat dalam mempertahankan pilihan ketika telah merasa nyaman pada metode kontrasepsi tertentu (72,1\%). Keputusan suami menjadi penentu dalam pengambilan keputusan metode kontrasepsi yang akan digunakan oleh pihak isteri. Disarankan adanya diseminasi kepada masyarakat setempat tentang kesetaraan gender dalam pengambilan keputusan khususnya dalam pemilihan kontrasepsi.
\end{abstract}

Kata Kunci : Peran Gender, Pengambilan Keputusan, Kontrasepsi 


\begin{abstract}
This study aims to determine the role of gender in decision making in the selection of contraceptive methods in Puskesmas Pattallassang, Gowa Regency.

This research is a descriptive survey to find out the role of gender in decision making for the choice of contraception among fertile age couples. A sample of 86 respondents were wives of fertile age couples who were family planning acceptors in the primary health care of Pattallassang Gowa working area.

The results showed that the husband dominated decision making using contraception (89.5\%), and the selection of contraceptive methods (57.0\%) in the primary health care of Pattallassang working area of Gowa Regency. While more wives were entrusted with making decisions on the choice of contraception to their husbands (57.0\%), their role was more visible in maintaining choices when they felt comfortable with certain methods of contraception (72.1\%).

The husband's decision becomes a determining factor in making the contraceptive method that will be used by the wife. It is recommended to disseminate to the local community about gender equality in decision making, especially in the selection of contraception.
\end{abstract}

Keywords: Gender Role, Decision Making, Contraception

\title{
PENDAHULUAN
}

Pengambilan keputusan dalam keluarga seharusnya dilakukan dengan jalan musyawarah antara suami dan istri secara setara untuk persoalan-persoalan penting dan skala besar bagi ukuran keluarga. Perubahan zaman membawa perubahan sosial, ekonomi dan teknologi yang berakibat pada perubahan pandangan terhadap keluarga termasuk dalam hal pengambilan keputusan (Puspitawati, 2013). Salah satu faktor yang memengaruhi hal tersebut adalah adanya emansipasi wanita yang memengaruhi persamaan hak-hak kaum wanita terhadap hak-hak kaum pria di segala bidang kehidupan. Emansipasi wanita bertujuan memberi wanita kesempatan bekerja, belajar, dan berkarya seperti halnya para pria, seimbang dengan kemampuannya. Hal-hal ini memengaruhi wawasan dan cara berfikir perempuan dalam berbagai segi kehidupannya, salah satunya dalam kehidupan berkeluarga. Kesetaraan dan keadilan gender dalam keluarga akan memperlancar kerjasama antar individu dan menurunkan tingkat 
kesalahpaahaman dan konflik dalam keluarga (Puspitawati, 2013), terutama dalam hal pengambilan keputusan.

Peran gender dalam keluarga dapat terlihat dalam bentuk pengambilan keputusan di tingkat keluarga, seperti pemilihan program Keluarga Berencana (KB). Program Keluarga Berencana merupakan usaha langsung yang bertujuan mengurangi tingkat kelahiran melalui penggunaan alat kontrasepsi yang lestari. Program KB mempunyai posisi yang strategis dalam upaya penanggulangan laju pertumbuhan penduduk melalui kelahiran, pendewasaan usia perkawinan, dan pembinaan ketahanan serta peningkatan kesejahteraan keluarga (Musu, 2012; Rahma, 2016).

Secara umum, konstruksi gender yang melembaga dalam dinamika sosial serta kultur di masyarakat saat ini telah memberikan beban ganda pada pihak isteri dalam rumah tangga, tidak terkecuali dalam hal kesehatan reproduksi berupa perencanaan anak, KB dan kontrasepsi (Fadhilah, 2014) .

Indonesia merupakan negara keempat dengan jumlah penduduk tertinggi di dunia dengan jumlah penduduk sekitar 235 juta, dan juga merupakan Negara berkembang. Peningkatan jumlah penduduk Indonesia cukup tinggi, berdasarkan data BPS terkait peningkatan jumlah penduduk pada tahun 2010 menunjukkan bahwa penduduk Indonesia dari tahun ke tahun mengalami peningkatan yakni 11.208.229 jiwa di tahun 1971, 147.490.298 juta jiwa di tahun $1980,179.378 .946$ jiwa di tahun 1990, 206.246.595 jiwa tahun 2000, dan tahun 2010 menjadi 237.641.326 jiwa (BPS, 2010).

Program KB ini menjadi salah satu kebijakan pemerintah yang memiliki fungsi strategis dalam upaya pengendalian laju pertumbuhan penduduk dan pembangunan ekonomi. Menurut teori Green and Kreuter (2005), perilaku seseorang dalam menetapkan pilihan kontrasepsi dipengaruhi oleh faktor faktor predisposisi (pengetahuan, sikap, karakteristik sosio-demografi), dan faktor pemungkin (lingkungan fisik, ketersediaan sarana dan prasarana).

Berbagai faktor memengaruhi tingkat penggunaan kontrasepsi. Suami masih memiliki peran yang kuat pengaruhnya untuk menentukan penggunaan metode KB oleh istri (Anggraeni, Hartati, \& Permana, 2007). Dukungan suami kepada isteri untuk menggunakan kontrasepsi jenis tertentu mencapai 100\% 
(Aryanti, 2014), dalam penggunaan kontrasepsi Metode Operasi Wanita (MOW) berupa tubektomi bagi isterinya lebih banyak suami tidak memberi dukungan sehingga isteri tidak memilih kontrasepsi MOW tersebut (Pasricha \& Biggs, 2010).

Budaya patrilineal yang masih kental dalam masyarakat, dan adanya anggapan bahwa Keluarga Berencana adalah urusan perempuan merupakan faktor yang memengaruhi pengambilan keputusan dalam Keluarga Berencana dan kesehatan reproduksi. Perempuan yang berperan sebagai isteri seringkali terabaikan haknya dalam sebuah rumah tangga, padahal hal tersebut merupakan hak yang paling hakiki, termasuk dalam keputusan menjadi akseptor (Balogun et al., 2016).

Berdasarkan hal tersebut di atas, penulis tertarik dalam meneliti peran gender dalam pengambilan keputusan pemilihan metode kontrasepsi di Puskesmas Pattallassang Kabupaten Gowa Tahun 2016.

\section{TINJAUAN PUSTAKA}

Istilah gender diperkenalkan oleh para ilmuwan sosial dalam menjelaskan perbedaan perempuan dan laki-laki yang bersifat bawaan sebagai ciptaan Tuhan dan bersifat bentukan budaya yang dipelajari dan melekat sejak kecil hingga dewasa (Puspitawati, 2013). Perbedaan peran gender ini membantu dalam penelaahan mengenai pembagian peran yang dianggap telah melekat pada perempuan dan laki-laki untuk membangun gambaran relasi gender yang dinamis dan tepat serta cocok dengan kenyataan yang ada dalam masyarakat. Perbedaan konsep gender secara sosial telah melahirkan perbedaan peran perempuan dan laki-laki dalam masyarakatnya. Secara umum adanya gender telah melahirkan perbedaan peran, tanggung jawab, fungsi dan bahkan ruang atau tempat dimana manusia beraktivitas. Perbedaan gender ini melekat pada cara pandang masyarakat, sehingga menganggap hal tersebut merupakan sesuatu yang permanen dan abadi sebagaimana permanen dan abadinya ciri biologis yang dimiliki oleh perempuan dan laki-laki (Puspitawati, 2013)

Dalam satu dekade terakhir, keberhasilan pelayanan Keluarga Berencana di Indonesia mengalami suatu keadaan stagnan yang ditandai dengan kurangnya perbaikan beberapa indikator KB yaitu CPR, unmet need dan Total Fertility Rate 
(TFR). Pemerintah Indonesia sangat mendukung program KB, bahkan sampai diatur dalam undang-undang. Sesuai dengan UU RI Nomor 36 Tahun 2009 tentang Kesehatan, pada pasal 78 disebutkan bahwa pemerintah bertanggung jawab dan menjamin ketersediaan tenaga, fasilitas pelayanan, alat dan obat dalam memberikan pelayanan keluarga berencana yang aman, bermutu, dan terjangkau oleh masyarakat.

Masalah utama bidang kependudukan yang dihadapi Indonesia adalah pertumbuhan penduduk yang relatif tinggi, sehingga menimbulkan ancaman terjadinya ledakan jumlah penduduk di Indonesia. Kurun waktu 10 tahun terakhir jumlah penduduk Indonesia senantiasa mengalami peningkatan, yaitu sebesar 32,5 juta dari jumlah tahun 2000 sebanyak 205,1 juta jiwa meningkat menjadi 237,6 juta jiwa pada tahun 2010.

Banyak hal yang memengaruhi akseptor dalam memilih alat kontrasepsi antara lain adalah pertimbangan medis, latar belakang sosial budaya, sosial ekonomi, pengetahun, pendidikan, dan jumlah anak yang di inginkan. Disamping itu adanya efek samping yang merugikan dari suatu alat kontrasepsi juga berpengaruh dalam menyebabkan bertambah atau berkurangnya akseptor suatu alat kontrasepsi.

\section{METODE PENELITIAN}

Jenis penelitian yang digunakan dalam penelitian ini adalah survey deskriptif untuk mengetahui peran gender dalam pengambilan keputusan pemilihan jenis kontrasepsi pada pasangan usia subur. Penelitian ini dilakukan di wilayah kerja Puskesmas Pattallassang Desa Sunggu Manai Kecamatan Pattallassang Kabupaten Gowa. Penelitian dilakukan pada bulan Mei 2016.

Populasi dalam penelitian ini adalah semua akseptor KB yang terdaftar di Puskesmas Pattalassang yang berasal dari Desa Sunggu Manai Kecamatan Pattallassang Kabupaten Gowa. Besarnya populasi yakni sebanyak 974 orang (PUS). Sementara sampel dalam penelitian ini sebanyak 86 orang, yang dipilih berdasarkan kriteria inklusi, yaitu: 1). Pasangan Usia Subur yang menjadi akseptor $\mathrm{KB}, 2)$. Bersedia menjadi responden. 
Instrumen pengumpulan data dalam penelitian ini adalah kuesioner yang memuat pertanyaan-pertanyaan terkait permasalahan yang diteliti, dan mampu memberikan kesimpulan yang representatif dari variabel-variabel yang diteliti. Adapun variabel independen dalam penelitian ini adalah: pendidikan, pengetahuan, sikap, nilai-nilai budaya, paritas, dan umur.

Data diolah dan dianalisis menggunakan SPSS untuk mengetahui peran gender dalam pengambilan keputusan pemilihan metode kontrasepsi. Data yang telah dianalisis disajikan dalam bentuk tabel, dan grafik disertai penjelasan dalam bentuk narasi.

\section{HASIL DAN DISKUSI}

\section{Karakteristik Responden}

Karakteristik responden dalam penelitian ini terdiri dari umur, pendidikan, pekerjaan, dan paritas dari responden (akseptor KB). Distribusi karakteristik responden di wilayah kerja Puskesmas Pattallassang Kabupaten Gowa tahun 2016 disajikan pada tabel 1 .

Tabel 1. Karakteristik Responden

\begin{tabular}{cccc}
\hline Karakteristik & Kategori & $\mathbf{n}$ & $\mathbf{\%}$ \\
\hline \multirow{2}{*}{ Umur } & $<20$ Tahun & 5 & 5,8 \\
& 20-35 Tahun & 60 & 69,8 \\
& $>35$ Tahun & 21 & 24,4 \\
\hline \multirow{2}{*}{ Pendidikan } & SD & 46 & 53,5 \\
& SMP & 17 & 19,8 \\
& SMA & 23 & 26,7 \\
\hline \multirow{2}{*}{ Pekerjaan } & IRT & 81 & 94,2 \\
& Petani & 4 & 4,7 \\
& Wiraswasta & 1 & 1,2 \\
\hline \multirow{2}{*}{ Paritas } & 1 Kali & 23 & 26,7 \\
& $2-3$ Kali & 51 & 59,3 \\
& $>3$ Kali & 12 & 14,0 \\
\hline
\end{tabular}

Sumber : Dara Primer, 2016.

Tabel 1 menunjukkan bahwa mayoritas responden berada pada kelompok umur 20-35 tahun yakni sebanyak 60 orang $(69,8 \%)$, dan responden lebih banyak memiliki pendidikan terakhir SD sebanyak 46 orang (53,5\%). Adapun jenis pekerjaan responden mayoritas merupakan IRT (ibu rumah tangga), yakni 
sebanyak 81 orang $(94,2 \%)$. Sementara paritas responden lebih dominan pada kelompok 2-3 kali sebanyak 51 orang $(59,3 \%)$.

\section{Pengetahuan \& Sikap Wanita Pasangan Usia Subur (PUS) tentang Kontrasepsi}

Berdasarkan dari hasil pengisian kuesioner, diketahui bahwa seluruh responden memiliki tingkat pengetahuan yang cukup terkait wawasan mengenai penggunaan dan pemilihan jenis kontrasepsi (100\%). Begitu pula dengan sikap wanita PUS tentang kontrasepsi yang menunjukkan bahwa keseluruhan responden memiliki sikap yang mendukung dalam penggunaan dan pemilihan jenis kontrasepsi (100\%).

\section{Pilihan \& Alasan Pemilihan Metode Kontrasepsi}

Hasil pengisian kuensioner menunjukkan pilihan metode kontrasepsi responden yang dapat dilihat pada tabel berikut ini.

Tabel 2. Pilihan Metode Kontrasepsi

\begin{tabular}{ccc}
\hline Metode Kontrasepsi & n (86) & \% \\
\hline Suntik & 76 & 88,4 \\
Implant & 10 & 11,6 \\
\hline
\end{tabular}

Sumber : Dara Primer, 2016.

Tabel 3. Alasan Pemilihan Jenis Kontrasepsi

\begin{tabular}{ccc}
\hline Alasan Pemilihan & n (86) & \% \\
\hline Tersedia di Puskesmas & 44 & 51,2 \\
Murah & 12 & 14,0 \\
Ajakan keluarga/Tetangga & 9 & 10,5 \\
Nyaman & 17 & 19,8 \\
Tidak Mau Hamil Lagi & 4 & 4,7 \\
\hline
\end{tabular}


Tabel 2 menunjukkan bahwa mayoritas responden memilih metode kontrasepsi suntik sebanyak 76 orang (88,4\%), dan tabel 3 menunjukkan bahwa alasan responden memilih metode kontrasepsi tertentu karena kontrasepsi tersebut tersedia di Puskesmas sebanyak 44 orang (51,2\%), dan hanya 4 orang $(4,7 \%)$ responden yang beralasan memilih metode kontrasepsi karena sudah tidak mau hamil lagi.

Adapun peran gender dalam pengambilan keputusan pemilihan metode kontrasepsi responden dapat dilihat pada tabel 4 berikut:

Tabel 4. Peran Gender dalam Pengambilan Keputusan Pemilihan Metode Kontrasepsi

\begin{tabular}{cccc}
\hline Peran Gender & Kategori & n (86) & \% \\
\hline Butuh Persetujuan Suami Untuk & Ya & 77 & 89,5 \\
Menggunakan Kontrasepsi & Tidak & 9 & 10,5 \\
\hline Butuh Persetujuan Suami Dalam Pemilihan & Ya & 49 & 57,0 \\
Jenis Kontrasepsi & Tidak & 37 & 43,0 \\
\hline \multirow{2}{*}{ Pengambilan Keputusan Oleh Pihak Isteri } & Ya & 17 & 19,8 \\
& Tidak & 69 & 80,2 \\
Tindakan Bila Suami Menyuruh Mengganti & Akan Mengganti & 24 & 27,9 \\
& Tetap pada Pilihan & 62 & 72,1 \\
\hline
\end{tabular}

Sumber : Dara Primer, 2016.

Tabel 4 menunjukkan bahwa mayoritas responden membutuhkan persetujuan suami untuk menggunakan kontrasepsi, yakni sebanyak 77 orang $(89,5 \%)$. Demikian halnya dalam pemilihan jenis kontrasepsi, mayoritas pihak isteri membutuhkan persetujuan suami yakni sebanyak 49 orang $(57,0 \%)$, dan hanya 17 responden $(19,8 \%)$ pengambilan keputusan dilakukan pihak isteri dalam memilih metode konrasepsi yang digunakan, dan ketika isteri diminta oleh suaminya untuk mengganti metode kontrasepsi yang digunakan maka pihak isteri sebanyak 62 orang $(72,1 \%)$ tetap mempertahankan metode kontrasepsi tersebut.

\section{Nilai Anak Dalam Keluarga}


Berdasarkan dari hasil pengisian kuesioner, maka nilai anak dalam sebuah keluarga dapat dilihat pada tabel 5 berikut ini.

Tabel 5. Nilai Anak Dalam Keluarga

\begin{tabular}{cccc}
\hline Nilai Anak & Kategori & n (86) & \% \\
\hline \multirow{2}{*}{ Banyaknya Anak } & Dua Anak Cukup & 40 & 46,5 \\
& Banyak Anak & 46 & 53,5 \\
\hline \multirow{2}{*}{ Alasan } & Biaya Terbatas & 33 & 38,4 \\
& Banyak Rejeki & 30 & 34,9 \\
& Ikut Program Pemerintah & 5 & 5,8 \\
& Terlalu Sedikit Bila Hanya Dua & 18 & 20,9 \\
\hline
\end{tabular}

Sumber : Dara Primer, 2016.

Adapun nilai anak lelaki dalam sebuah keluarga dapat dilihat pada tabel 6 berikut ini.

Tabel 6. Nilai Anak Lelaki Dalam Keluarga

\begin{tabular}{cccc}
\hline Nilai Anak & Kategori & n (86) & \% \\
\hline \multirow{2}{*}{ Harus Memiliki Anak Lelaki } & Ya & 79 & 91,9 \\
& Tidak & 7 & 8,1 \\
\hline \multirow{2}{*}{ Alasan } & Menjaga Kehormatan Keluarga dan & 52 & 60,5 \\
& Pencari Nafkah & 27 & 31,4 \\
& Terasa Lengkap & 7 & 8,1 \\
\hline
\end{tabular}

Sumber : Dara Primer, 2016.

Adapun nilai anak perempuan dalam sebuah keluarga dapat dilihat pada tabel 7 berikut ini.

Tabel 7. Nilai Anak Perempuan Dalam Keluarga

\begin{tabular}{cccc}
\hline Nilai Anak & Kategori & n (86) & \% \\
\hline $\begin{array}{c}\text { Harus Memiliki Anak } \\
\text { Perempuan }\end{array}$ & Ya & 76 & 88,4 \\
& Tidak & 10 & 11,6 \\
\hline \multirow{2}{*}{ Alasan } & $\begin{array}{c}\text { Membantu Kegiatan Rumah } \\
\text { Tangga dan Memelihara di Hari } \\
\text { Tua }\end{array}$ & 49 & 57,0 \\
& Terasa Lengkap & 27 & 31,4 \\
& Tidak Harus Ada Anak Perempuan & 10 & 11,6 \\
\hline
\end{tabular}

Sumber : Dara Primer, 2016. 
Tabel 7 menunjukkan bahwa mayoritas responden merasa harus memiliki anak perempuan dalam keluarganya $(88,4 \%)$ dengan alasan tertinggi yakni peran anak perempuan diharapkan dapat membantu kegiatan rumah tangga dan memelihara di hari tua kelak $(60,5 \%)$.

\section{Diskusi}

\section{Peran Suami Dalam Pengambilan Keputusan Pemilihan Metode Kontrasepsi}

Gender secara umum mencerminkan perbedaan yang tampak antara laki - laki dan perempuan yang dilihat dari nilai dan tingkah laku. Dalam Women Studies Ensiklopedia dijelaskan bahwa gender merupakan suatu konsep kultural yang berupaya membuat perbedaan (distriction) dalam hal peran, perilaku, mentalitas dan karakteristik emosional antara laki-laki dan perempuan yang berkembang di masyarakat (Nurlisis \& Angraini, 2016).

Dalam penelitian ini, mayoritas responden membutuhkan persetujuan suami untuk menggunakan kontrasepsi, yakni sebanyak 77 orang $(89,5 \%)$. Begitu pula dengan pemilihan metode kontrasepsi mayoritas membutuhkan persetujuan suami, yakni sebanyak 49 orang $(57,0 \%)$, dan hanya 17 responden $(19,8 \%)$ pihak isteri yang memutuskan metode kontrasepsi yang akan digunakan. Ini membuktikan bahwa besarnya peranan suami dalam penentuan metode kontrasepsi yang akan digunakan oleh pihak isteri. Hal ini sejalan dengan penelitian yang dilaporkan oleh Mboane and Bhatta (2015) yang menyatakan bahwa peran laki-laki begitu besar dalam pemilihan alat kontrasepsi dibandingkan pihak isteri di Mozambik.

Salah satu ketimpangan dalam konsep gender adalah subordinasi, yakni adanya aggapan bahwa perempuan lemah, tidak mampu memimpin, cengeng dan lain sebagainya, mengakibatkan perempuan menjadi nomor dua setelah lakilaki. Terlebih lagi pada daerah sarat akan budaya yang berpengaruh terhadap gender. Harapan masyarakat bahwa perempuan dan laki-laki harus berpikir, berperasaan dan betindak dengan pola-pola tertentu dengan alasan karena mereka dilahirkan sebagai perempuan/laki-laki. Gender dan kegiatan yang dihubungkan dengan jenis kelamin tersebut, semuanya adalah hasil rekayasa masyarakat. Bahkan, pada beberapa wilayah tertentu, peran jenis kelamin 
dipengaruhi oleh tingkat pendidikan, suku dan umurnya. Akhirnya, anutan gender yang seperti ini diajarkan secara turun temurun dari orang tua ke anaknya. Sejak anak berusia muda, orang tua telah memperlakukan anak perempuan dan lelaki berbeda, meskipun terkadang tanpa disadari.

Dalam konsep gender yang dikenal adalah peran gender individu di masyarakat, sehingga kelompok masyarakat mengenal maskulinitas dan feminimitas. Sebagai gambaran, sesuatu yang dianggap maskulin dalam satu kebudayaan bisa dianggap sebagai hal yang feminim dalam budaya lain. Dengan kata lain, ciri maskulin ataupun feminim itu tergantung dari konteks sosial-budaya, bukan hanya pada perbedaan jenis kelamin, karena Gender merupakan perilaku atau pembagian peran antara laki-laki dan perempuan yang sudah dikonstruksikan atau dibentuk di masyarakat tertentu dalam waktu tertentu (Tahar, 2012).

Ada berbagai faktor yang memengaruhi wanita PUS menjadi akseptor kontrasepsi, antara lain faktor pendidikan, faktor pengetahuan, faktor paritas dan faktor budaya (kepercayaan). Selain faktor-faktor di atas, ternyata pemilihan jenis kontrasepsiyang akan digunakan juga tergantung dari kebutuhan masing-masing akseptor. Kebanyakan akseptor menjatuhkan pilihannya berdasarkan tujuan berkontrasepsi, seperti untuk menunda atau menjarangkan kehamilan yang kerap dipilih oleh PUS reproduksi sehat (20-35 tahun), atau bahkan untuk mengakhiri kehamilan yang biasanya dipilih oleh yang berusia 36-45 tahun (BKKBN, 2003).

Faktor pendidikan seseorang sangat menentukan dalam pola pengambilan keputusan dan penerimaan informasi daripada seseorang yang berpendidikan rendah. Pendidikan juga akan memengaruhi pengetahuandan persepsi seseorang tentang pentingnya suatu hal, termasuk perannyadalam pemilihan metode kontrasepsi. Pada akseptor kontrasepsi dengan tingkat pendidikan rendah, keikutsertaannya dalam program kontrasepsi hanya ditujukan untuk mengatur kelahiran. Sementara itu pada akseptor dengan tingkat pendidikan tinggi, keikutsertannya bukan hanya mengatur kelahiran, tetapi juga untuk meningkatkan kesejahteraan keluarga. Hal ini disebabkan seseorang dengan tingkat pendidikan lebih tinggi memiliki pandangan yang lebih luas tentang suatu hal dan lebih mudah untuk menerima ide atau cara kehidupan baru. Dengan demikian, tingkat 
pendidikan juga memiliki hubungan dengan pemilihan jenis kontrasepsi yang akan digunakan (BAPPENAS, 2009).

Dalam penelitian ini, mayoritas responden memiliki tingkat pendidikan SD (53,5\%), dan hanya 26,7\% yang mencapai tingkat SMA. Hal ini memberikan gambaran bahwa seorang isteri lebih menyerahkan posisi pembuat keputusan kepada suaminya, khususnya dalam pemilihan metode kontrasepsi yang digunakan. Pendidikan seorang isteri dapat membantu meningkatkan pengetahuan tentang metode kontrasepsi yang tersedia, memungkinkan individu untuk membuat keputusan berdasarkan informasi dan menggunakan kontrasepsi secara lebih efektif (Pazol. etc, 2015). Terlebih lagi 94,2\% diantaranya bekerja sebagai Ibu Rumah Tangga (IRT), yang lebih banyak menghabiskan waktu dengan aktivitas rumah tangga dan menjaga anak, serta menggantungkan masalah perekonomian kepada pihak suami. Perilaku inilah yang menyebabkan tingkat sisi "penurut" dan tidak berani mengambil keputusan sendiri semakin besar. Pihak suami dianggap lebih mampu mengambil keputusan, terlebih pada situasi budaya yang senantiasa menomorsatukan pihak suami.

Pelayanan kontrasepsi akan berhasil dengan baik bila masyarakat mengenal berbagai jenis kontrasepsi yang tersedia. Akan tetapi, pengenalan berbagai jenis kontrasepsi ini cukup sulit karena hal ini menyangkut pola pengambilan keputusan dalam masyarakat itu sendiri. Proses pengambilan keputusan untuk menerima suatu inovasi ditentukan oleh tahap pengetahuan (knowledge) dan tahap konfirmasi (confirmation). Suatu inovasi dapat diterima maupun ditolak setelah melalui tahap-tahap tersebut. Inovasi ditolak bila inovasi tersebut dipaksakan oleh pihak lain, atau inovasi tersebut tidak dipahami, sehingga inovasi tersebut dinilai sebagai ancaman terhadap nilai-nilai masyarakat setempat. Sementara itu, inovasi yang diterima tidak akan diterima secara menyeluruh tetapi bersifat selektif dengan berbagai macam pertimbangan, karena tingkat pengetahuan masyarakat akan memengaruhi penerimaan program KB terkhusus pemilihan Metode Kontrasepsi yang akan digunakan oleh pihak isteri.

\section{Peran Isteri Dalam Pengambilan Keputusan Pemilihan Metode Kontrasepsi}

Wujud kesetaraan gender dalam keluarga dapat terwujud pada akses yang dapat diartikan sebagai kapasitas untuk menggunakan sumberdaya yang 
sepenuhnya berpartisipasi secara aktif dan produktif. Selain itu, partisipasi wanita juga merupakan salah satu wujud kesetaraan gender dalam keluarga, yakni wujud sebagai siapa melakukan apa. Suami dan isteri mampu memberikan partisipasi yang sama dalam proses pengambilan keputusan atas penggunaan sumberdaya keluarga secara demokratis dan bila perlu melibatkan anak-anak, baik laki-laki maupun perempuan. Salah satu dari wujud kesetaraan gender dalam partisipasi keluarga adalah dalam pengambilan keputusan pemilihan metode kontrasepsi yang akan digunakan pada tubuh sosok isteri.

Dalam kesetaraan menggunakan kontrasepsi meliputi kasus kematian ibu dan infertilitas, kesetaraan dan keadilan gender yang dapat diupayakan antara lain meliputi:

a. Suami dan istri secara bersama merencanakan jumlah dan jarak kelahiran anak dengan mempertimbangkan faktor usia, kesehatan, kesiapan mental dan ekonomi keluarga. Dengan pembahasan dan upaya bersama ini istri tidak diabaikan dalam menentukan kesehatan reproduksinya.

b. Suami dan istri berupaya memperoleh informasi yang seimbang dan akurat tentang kontrasepsi sehingga keputusan yang diambil merupakan keputusan bersama, bukan salah satu pihak saja. Keputusan bersama untuk menjadi akseptor kontrasepsi sebaiknya didasari oleh pengetahuan yang tepat (well-informed) sehingga dapat memberikan pilihan yang tepat atas obat/alat/metode kontrasepsi yang dipilih (informed choice).

c. Suami dan istri secara bersama menentukan siapa yang sebaiknya menjadi akseptor kontrasepsi, obat/metode kontrasepsi yang dipilih. Dengan kebersamaan ini tidak terjadi pemaksaan terhadap suami atau istri melalui pertimbangan yang matang dilihat dari berbagai aspek.

d. Suami dan istri menanggulangi bersama permasalahan apabila terjadi kegagalan atau komplikasi dengan cara mengunjungi tempat pelayanan yang tersedia di lingkungan tempat tinggal mereka. Hal ini penting artinya karena keputusan metode/alat/obat kontrasepsi serta 
tempat dan tenaga pelayanan yang dipilih telah diputuskan bersama, tanpa ada lagi sikap saling menyalahkan atau saling berkecil hati.

Selain itu paritas turut berpengaruh terhadap pengambilan keputusan. Adapun paritas yang dimaksud di sini adalah berapa kali ibu melahirkan di dalam satu keluarga sampai pada saat wawancara diilakukan (BPS,2010). Setiap anak memiliki nilai, karena setiap anak merupakan cerminan harapan serta keinginan orang tua yang menjadi pedoman dari pola pikir, sikap maupun perilaku dari orang tua tersebut. Dengan demikian, setiap anak yang dimiliki oleh pasangan suami istri akan memberi pertimbangan tentang apakah mereka ingin memiliki anak dan jika ingin,berapa jumlah yang diinginkan. Jumlah anak berkaitan erat dengan tingkat kesejahteraan keluarga.

Perbedaan gender tidak hanya terjadi ketika PUS menentukan pilihan metode kontrasepsi, bahkan hingga anak yang diinginkan dalam rumah tangga.

Pada keluarga dengan tingkat kesejahteraan tinggi mumnya lebih mementingkan kualitas anak dari pada kuantitas anak. Sementara itu pada keluarga ekonomi ke bawah, anak dianggap memiliki nilai ekonomi. Umumnya keluarga ekonomi bawah memiliki banyak anak dengan harapan anak-anak tersebut dapat membantu orang tuanya bekerja. Dalam penelitian ini, mayoritas responden lebih memilih memiliki banyak anak (53,5\%) dibandingkan dengan hanya memiliki dua anak saja 946,5\%). Alasan tertinggi yang dikemukakan adalah biaya yang terbatas dari keluarga $(38,4 \%)$. Hal ini membuktikan bahwa kuantitas anak yang diharapkan dalam keluarga bukan hanya ditentukan oleh keinginan untuk melengkapi keluarga dengan anak lelaki dan perempuan, tetapi juga memikirkan aspek ekonominya.

Jumlah anak juga dapat dipengaruhi oleh faktor kebudayaan setempat yang menganggap anaklaki-laki lebih bernilai dari anak perempuan.Hal ini mengakibatkan pasangan suami istri berusaha untuk menambah jumlah anak mereka jika belum mendapatkan anak laki-laki.Hal ini sejalan dengan penelitian ini yang menunjukkan bahwa responden yang menyatakan harus memiliki anak lelaki sebanyak 91,9\%, sementara pernyataan harus memiliki anak perempuan sebanyak $88,4 \%$. Begitu pula dengan hasil yang menyatakan bahwa ketidakharusan dalam 
memiliki anak lelaki lebih rendah $(8,1 \%)$ dibandingkn dengan anak perempuan $(11,6 \%)$.

Jumlah anak berkaitan erat dengan program kontrasepsi (Keluarga Berencana) karena salah satu misi dari program Keluarga Berencana adalah terciptanya keluarga dengan jumlah anak yang ideal dan terencana, dengan penilaian anak lelaki maupun perempuan sama saja atau memiliki kedudukan yang sama pentingnya dalam satu keluarga. Para wanita umumnyalebih menyadari bahwa beberapa jenis kelamin anak tidak penting sehinggabila jumlah anak sudah dianggap ideal maka para wanita cenderung untukmengikuti program kontrasepsi, baik yang berlaku jangka pendek maupun yang bersifat jangka panjang (BKKBN, 2010).

\section{SIMPULAN DAN IMPLIKASI}

Adapun kesimpulan dari hasil penelitian ini adalah sebagai berikut.

1. Suami menunjukkan dominansi dalam pengambilan keputusan menggunakan kontrasepsi $(89,5 \%)$, dan pemilihan metode kontrasepsi $(57,0 \%)$ di wilayah kerja Puskesmas Pattallassang Kabupaten Gowa.

2. Isteri masih lebih banyak yang mempercayakan pengambilan keputusan pemilihan metode kontrasepsi kepada suami (57,0\%), namun perannya lebih terlihat dalam mempertahankan pilihan ketika telah merasa nyaman pada metode kontrasepsi tertentu $(72,1 \%)$ di wilayah kerja Puskesmas Pattallassang Kabupaten Gowa. 


\section{DAFTAR PUSTAKA}

Anggraeni, M. D., Hartati, \& Permana, R. H. (2007). Peran suami dalam penggunaan alat kontrasepsi yang berwawasan gender. Keperawatan Soedirman (The Soedirman Journal of Nursing), 2.

Aryanti, H. (2014). Faktor-faktor yang berhubungan dengan penggunaan alat kontrasepsi pada wanita kawin usia dini di kecamatan aikmel kabupaten Lombok Timur. Tesis. Universitas Udayana Denpasar. Denpasar.

Balogun, O., Adeniran, A., Fawole, A., Adesina, K., Aboyeji, A., \& Adeniran, P. (2016). Effect of Male Partner's Support on Spousal Modern Contraception in a Low Resource Setting. Ethiopian journal of health sciences, 26(5), 439-448. doi: 10.4314/ejhs.v26i5.5

BAPPENAS. (2009). Kependudukan dan Keluarga Berencana. Jakarta: Bappenas.

BKKBN. (2010). Profil KB dan Kependudukan Tahun 2010. Jakarta: BKKBN.

BPS. (2010). Proyeksi Penduduk Indonesia (Indonesia Population Projection). Jakarta: BPS.

Fadhilah, N. A. (2014). Implementasi Konsep Kesetaraan Gender (Studi Peran Suami dalam Kesehatan Reproduksi Istri di Dusun Badegan Kabupaten Bantul). Skripsi. Sosiologi Agama Fakultas Ushuluddin dan Pemikiran Islam. UIN Sunan Kalijaga. Yogyakarta.

Green, L., \& Kreuter, M. (2005). Health Program Planning : An Educational and Ecological Approach. Fourth Edition. New York: McGraw-Hill.

Mboane, R., \& Bhatta, M. (2015). Influence of a husband's healthcare decision making role on a woman's intention to use contraceptives among Mozambican women. Reproductive health, 12, 36. doi: 10.1186/s12978015-0010-2

Musu, A. B. (2012). Faktor-Faktor yang berhubungan dengan Pemakaian Kontrasepsi Implan pada Akseptor KB Di Puskesmas Ciomas Kecamatan Ciomas, Kabupaten Bogor Tahun 2012. Skripsi. Fakuktas Kesehatan Masyarakat; Kebidanan Komunitas. Universitas Indonesia. Jakarta.

Nurlisis, \& Angraini, W. (2016). Hubungan Pengetahuan Ibu Dan Dukungan Suami Dengan Pemakaian Kontrasepsi Jangka Panjang Di Wilayah Kerja Puskesmas Rumbai Pesisir. Jurnal Photon, 6(2).

Pasricha, S. R., \& Biggs, B. A. (2010). Undernutrition among children in South and South-East Asia. J Paediatr Child Health, 46(9), 497-503. doi: 10.1111/j.1440-1754.2010.01839.x

Pazol, K., Zapata, L. B., Tregear, S. J., Mautone-Smith, N., \& Gavin, L. E. (2015). Impact of Contraceptive Education on Contraceptive Knowledge and Decision Making: A Systematic Review. American journal of preventive medicine, 49(2 Suppl 1), S46-S56. doi: 10.1016/j.amepre.2015.03.031 
Puspitawati, H. (2013). Interaksi suami istri dalam mewujudkan harmonisasi keluarga responsif gender. Bogor: Institut Pertanian Bogor.

Rahma, M. (2016). Univertas Lampung. Lampung.

Tahar. (2012). Pengaruh Diskriminasi Gender Dan Pengalaman Terhadap Profesionalitas Auditor. Univeritas hasanuddin. Makassar. 